\title{
Neuronal MHC-I display in T-cell mediated neurodegeneration
}

\author{
Carolina Cebrián ${ }^{1}$, Fabio Zucca², Luigi Zecca², John Loike', David Sulzer ${ }^{1 *}$ \\ From Molecular Neurodegeneration: Basic biology and disease pathways \\ Cannes, France. 10-12 September 2013
}

Parkinson's disease (PD) and other disorders feature the degeneration of ventral midbrain (VM) catecholamine neurons. Recent data suggest that neuroinflammatory mechanisms contribute to a cascade of events leading to chronic neuronal degeneration.

In primary murine neuronal cultures, substantia nigra (SN) and locus coeruleus (LC) neurons are induced to express the major histocompatibility class I complex (MHC-I) by the proinflammatory cytokine, $\gamma$-interferon, L-DOPA, or conditioned medium from microglia exposed to $\alpha$-synuclein or NM. SN DA neurons, moreover, process the foreign protein ovalbumin to an antigenic peptide that is presented by their MHC-I and triggers their specific destruction by CD8+ killer T-cells. In human postmortem samples, we find by immunolabel, mRNA profiling, and proteomic analysis that neuromelanin (NM)-containing catecholamine SN and LC neurons in adult human control and PD brains express MHC-I, often in proximity to CD8+ T-cells. These data reveal a novel inflammatory $\mathrm{T}$-cell mediated neurodegenerative processes that could underlie neuronal death.

\section{Authors' details}

${ }^{1}$ Columbia University, New York, USA. ${ }^{2}$ Italian National Research Council,

Milano, Italy.

Published: 13 September 2013

doi:10.1186/1750-1326-8-S1-P38

Cite this article as: Cebrián et al:: Neuronal MHC-I display in T-cell

mediated neurodegeneration. Molecular Neurodegeneration 2013

8(Suppl 1):P38.

${ }^{1}$ Columbia University, New York, USA

Full list of author information is available at the end of the article

Submit your next manuscript to BioMed Central and take full advantage of:

- Convenient online submission

- Thorough peer review

- No space constraints or color figure charges

- Immediate publication on acceptance

- Inclusion in PubMed, CAS, Scopus and Google Scholar

- Research which is freely available for redistribution 